UDC 336.2:330.4

DOI: 10.18523/2519-4739.2021.6.1.52-58

H. Hryhoriev

\title{
PATH DEPENDENCE IN SOVEREIGN DEBT MODELLING: SYSTEM DYNAMICS APPROACH
}

The article offers a system dynamic modelling of sovereign debt using the path dependence concept. Using simulation modelling we are trying to find a fixed point in a motion of national sovereign debt towards its equilibrium and to change the existing mental model perception towards sovereign debt by changing the structure of the system.

The research reveals the idea of the "debt snowball concept" using recursive dynamic approach. The dynamic linear and nonlinear recursive models of Ukrainian sovereign debt with the appropriate multiorder recursive equations are constructed. The fixed point as an equilibrium value for a country's sovereign debt stock to GDP ratio with a linear dependence has been built. Finding the initial point for resolving sovereign debt issue is especially actual for national economy under strong fiscal pressure caused by COVID-19 and wartime on the East of the country. For this purpose, the sovereign debt cyclical behaviour was also reproduced using phase plot graphic.

The fixed point as an equilibrium value for a country's sovereign debt stock to GDP ratio with a nonlinear dependence was determined. The main purpose of this part of the analysis was to show the more complicated oscillated behaviour of the system and the multiplicity of possible equilibrium points.

The stock and flows SD modelling and simulation analysis of sovereign debt in Ukrainian economy allows to make the conclusion of the inevitability of the sovereign debt existence even on the stable level and with the balanced national budget.

Keywords: system dynamics, path dependence, debt "snowball" concept, linear and non - linear sovereign debt model, oscillation, lock in.

\section{JEL classification: E60, H63, H68}

Introduction and research problem. Ukrainian economy is on the path to overcome economic downturn and to reduce substantially the sovereign debt level. Nevertheless, it is still under considerable pressure of sovereign debt fluctuations nowadays. There are a lot of overseas scientific sources, which explain the role of budget deficit in debt overhang and economic growth slowdown, but not so many in Ukraine (Picarelli, Vanlaer \& Marneffe, 2019).

In our paper we describe the vulnerability of national economy under circumstances of debt overhang, budget deficit and investment crowding out. "The debt overhang arises in a situation in which the debtor country benefits very little from the return to any additional investment because of debt service obligations" (Borensztein, 1990). The article is devoted to the problem of sovereign debt as a continual of logical interconnected steps (path dependence).

In our research we define the outcome probability of the sovereign debt critical increasing which may lead to sovereign default and depends (or has an impact) on the series of previous events (especially sovereign defaults and debt restructuring). In turn the historical events have the critical importance in a path dependence event. The sovereign debt precedence in a past creates the chain of events (including sovereign debt noose) which influence on a nowadays policy decisions. One of the core tasks of the research is to define the critical policy decisions which have led to a serious debt problem as a current economic outcome. It means, that choice in the past formats the modern mental structure.

Recent publications analysis. The issue of modelling and research of the path dependence as a pattern of behaviour of random events predetermines the solution of dynamic equilibrium and has been preoccupied in a lot of research. The methodological roots of path dependence theory are in the life cycle paradigm of T. Kuhn (Kuhn, 1970; Sterman \& Wittenberg, 1990), where he proposes the pattern of punctuated equilibrium, which is retransformed later into path dependence theory and "model of paradigm emergence and competition" by a group of scientists (Sterman \& Wittenberg, 1990), where the destiny of the specific new research is 
predetermined by incidents encircling its modelling and insubstantially by formalization process.

The applied ideas of path dependence started in works of (David, 1985), where the continuity of interdependence between cause and effects variables on a remote basis has been described. The methodology of path dependence was developed later in works of (Vergne \& Durand, 1990), where the issue of path dependence random event as a cause with unexpected effects and scientific empirical estimation of the problem was addressed. The dissertation of (Cha, 2019) describes the theory of path dependence as a social game theory between agents as the self - organizing dynamics process, contrary to the random one.

Unsolved parts of the problem. Despite the huge amount of works, dedicated to methodological problems of path - dependence in system dynamics and sovereign debt issues, there is a lack of publications which join those still separated parts of the research. The peculiar attention to the problem of sovereign debt issues in Ukraine, which are related to the possible negative outcomes of external debt resolution, even in the form of sovereign default, requires the appropriate scientific rationale. Time path dependence, as a trajectory of sovereign debt development provides the tools to reveal the hidden mechanism of the general theoretical and specifically national root cause of the excessive indebtedness existence and the possible way out of the situation. There is a lack of scientific ideas, which can clearly identify the trigger point for disequilibrium process in macroeconomics, especially in the field of non linear dynamics of external debt with appropriate simulation model for further scenario development. The tactical and strategical policy analysis is impossible without existence of appropriate dynamic model in the time of semi - chaotic beginning of the new global economic and financial development, which causes the rebuilding of the national economic systems. The main unresearched scientific question, which still exists: "Does history really matter in the emergence of sovereign debt and how to create the positive feedback mechanism to avoid the "debt trap"?"

Research goal and questions. The main goal of this research, based on the principles of system dynamics is to form the dynamic equilibrium simulation model of the Ukrainian sovereign debt market using the path dependence structure of growth creation with further development and implementation of plausible dynamical scenarios which allows to overcome the internal policy resistance and to create the matrix of possible negative and positive sovereign debt outcomes for
Ukrainian economy. The subtasks to achieve during the research are: to form the very basic sovereign debt path dependent linear and linear model using a continuous function of time and introducing the "debt snowball concept" with the appropriate recursive dynamic approach; to create the linear model with the starting value of the sovereign debt time path; to present the phase plot graphical solution for sovereign debt behaviour; to present the fixed point with appropriate equilibrium value for a country's sovereign debt stock to GDP ratio with a nonlinear dependence; to provide simulation analysis of sovereign debt in Ukrainian economy with possible national sovereign debt market scenario analysis. The results of modelling will help to redesign the existing national mental model and appropriate barriers to learning as the specific dynamic instrument.

Main findings. The record sum of the global debt, which approaches the USD $277 \mathrm{trln}$. by different evaluations in 2021, causes the negative shocks on developing economies investment sector and macroeconomic stability in general. It is especially actual for Ukraine, where the wartime and COVID-19 caused government expenditures to soar. On the other hand, the effective use of external debt leads to the accumulation of capital stock and long - run economic growth. Here we observe the main theoretical and empirical issue of the sovereign debt negative experience trajectory and the problem of this path - dependence overcoming. The modern sovereign debt challenges for developing and developed countries are different: for the latter one the main issue is crowding - out of private investment; the former are suffering from critical extra spending on COVID-19 fighting and inability to improve the sovereign risk indicators with appropriate effects. Therefore, the risk of sovereign default and sliding to the category of "phantom debtor" in Ukraine is increasing, which threatens the existence of the independent state. To evaluate properly the dynamics of sovereign debt we need to use the well - known indicator of sovereign debt/GDP, which reflects the annual dynamics. The general comparative dynamics is presented on Figure 1.

Main purpose of research is to implement one of the basic dynamic concepts - time path dependence, into sovereign debt sphere of analysis with the elaborating the appropriate model using the continuous dynamic model. One of the main questions, we are trying to answer is: "Is sovereign debt dynamic equilibrium (in Ukraine) stable, unstable or moving around?" To formalize the problem and to find out the dynamic change of the variable (contrary to static change), we apply the 


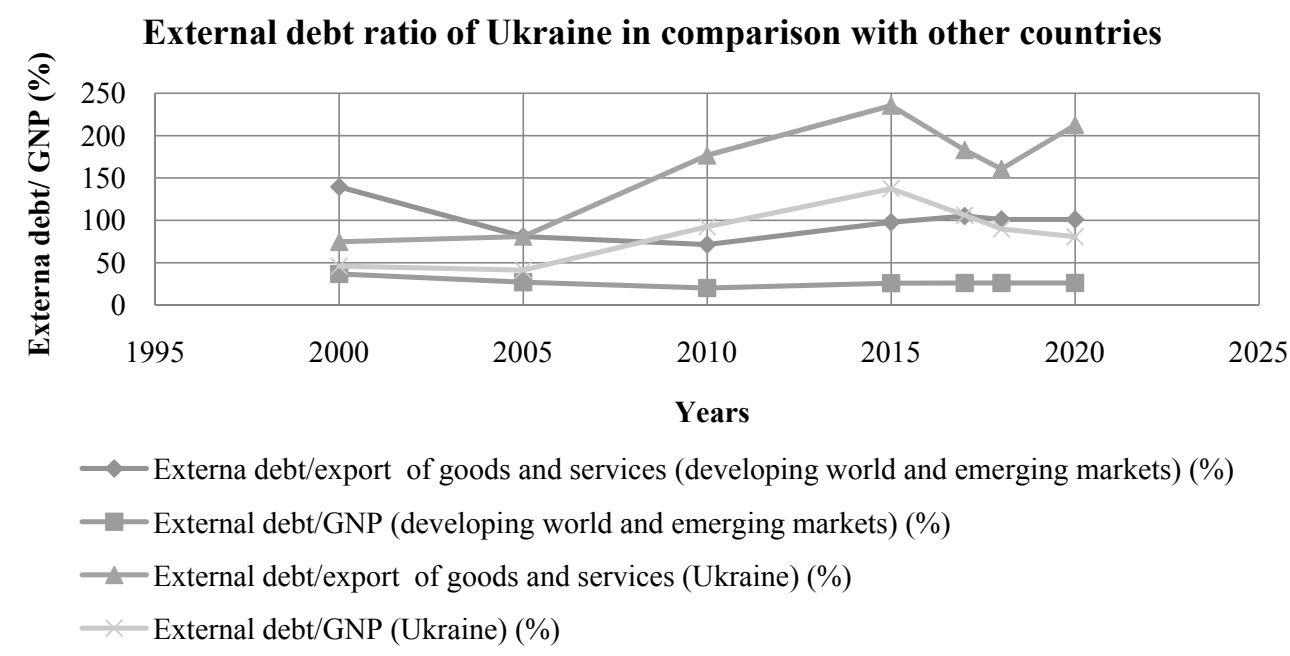

Fig. 1. The dynamics of external debt /GNP ratio of Ukraine in 2000-2018 in comparison with other countries Source: State Statistics Service of Ukraine

"debt snowball concept" (Hugh, 2010) using recursive dynamic approach (with an interpretation of (Escolano, 2010):

$$
\frac{D_{t}}{Y_{t}}-\frac{D_{t-1}}{Y_{t-1}}=\frac{P D_{t}}{Y_{t}}+\left(\frac{D_{t-1}}{Y_{t-1}} * \frac{i_{t}-y_{t}}{1+y_{t}}\right)+\frac{S F_{t}}{Y_{t}}
$$

where $\boldsymbol{D}$ is the sovereign debt level, $\boldsymbol{Y}$ is nominal GDP, $\boldsymbol{P D}$ is the primary deficit, $\boldsymbol{i}$ is the average (nominal) interest paid on government debt, $\boldsymbol{y}$ is the nominal GDP growth rate and $\boldsymbol{S F}$ is the stock-flow adjustment. The balance of forces in the above mentioned model is a complex number of the interrelation between the group of indicators. The dimensionless number $\left(\mathrm{x}^{*}\right)$ establishes this balance of forces between the parameters and named equilibrium constant. This research is very basic one but may be extended to Poisson distribution for finding the probability of equilibrium existence in a future. The dynamic recursive models are presented in the research in linear and nonlinear form with the period of 1991-2018 for Ukrainian economy, which gives us the multi - order recursive equation.

Linear model. The starting value of the sovereign debt time path is proceeded from the zero level of sovereign debt in $1991(\mathrm{X}(0)=0)$. The calculation within the above presented formula (1) has created the linear formula with the appropriate graph of the following type:

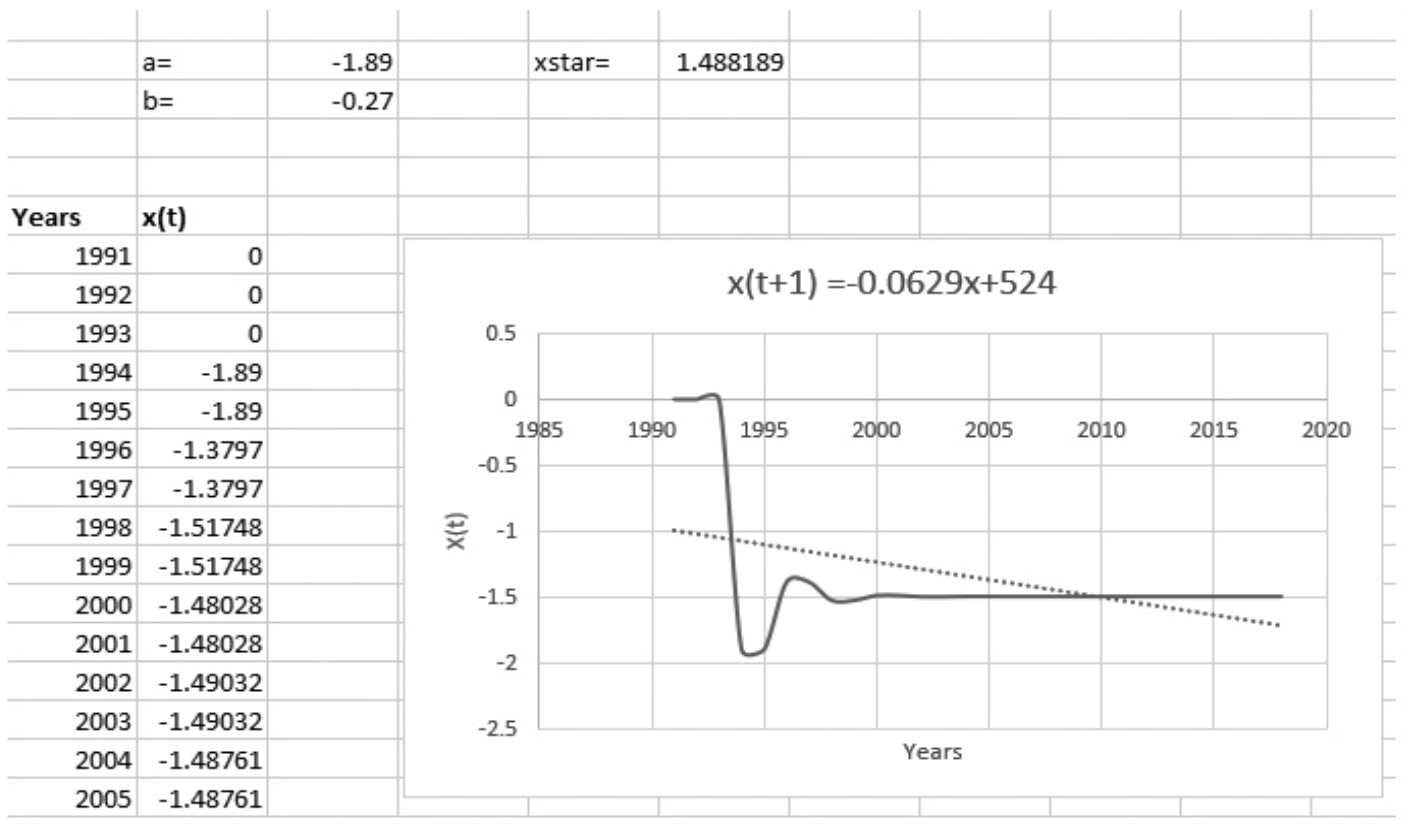

Fig. 2. Finding the fixed point as an equilibrium value for a country's sovereign debt stock to GDP ratio with a linear dependence (fragment of the calculation) Source: own calculations, based on (Shone, 2003) 
The deterministic dynamical model in a difference form looks like:

$$
x(t+1)=-0.0629 x+524 \quad X(0)=X_{0}
$$

The fixed point (equilibrium) of the system (the resulting time path of $x(t)$ ) is on the level of -1.488 . Any change to the parameter value is immediately reflected in a change to the equilibrium value (Shone, 2003, p. 8). The stability of equilibrium is starting with the value 0 and the fact that the current equilibrium point has taken the form of an attractor fixed point.

Phase plot graphical solution. On the Fig. 2, presented below, "the fixed point is attracting the system from any position on either side" (Shone, 2003 , p. 13). Session is presented by years of analysis. The sovereign debt behaviour is reflected by the frequency of the problem. The figure shows us the possible parts of the sovereign debt cycle with an increasing movement to a straight line.

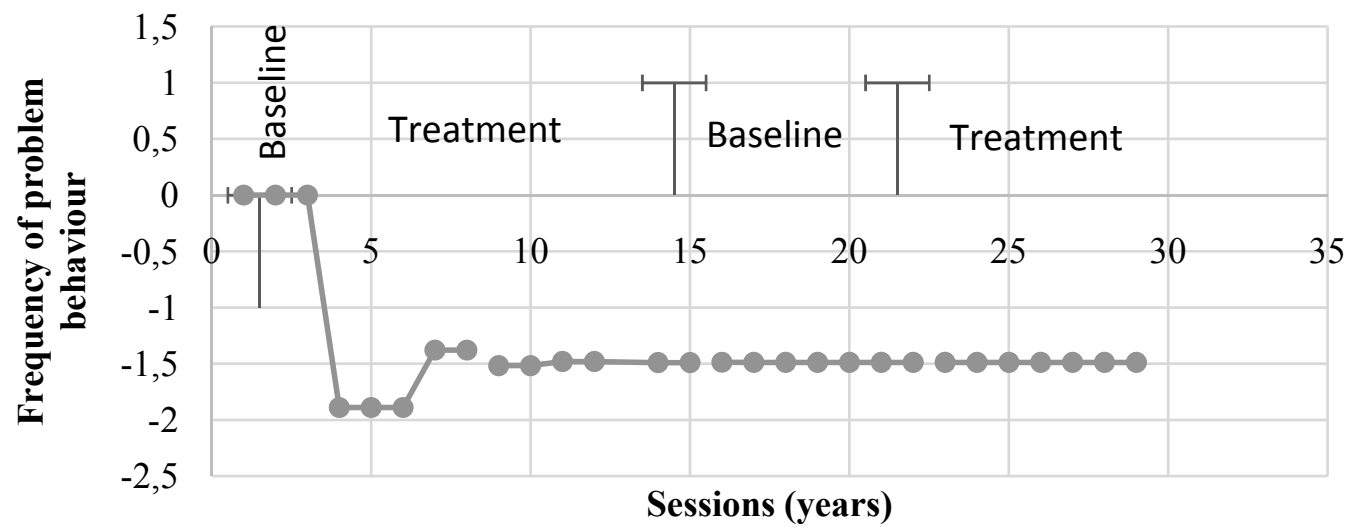

Fig. 3. Phase plot graphical solution for sovereign debt dynamics Source: own calculations, based on (Shone, 2003)

tending to the equilibrium of -1.488 (pointed "x star" on the spreadsheet). The system will always converge itself (in other words, oscillating between the repelling and attracting) to the equilibrium, whatever basic level is being chosen. Identically to (Shone, 2003) changing the parameter $a$ of the linear model, or 524 in our example will change the equilibrium value and changing the parameter $b$ or -0.0629 ("system is oscillating, but converging on the equilibrium value" (Shone, 2003, p. 10) of the model will substantially change the initial fixed point, not depending on the sign (positive or negative). Under the parameter value $b$ of 1 the model attains practically the negative form with the slight oscillations between periods of time and no fixed point. The economic sense of changing the parameter $\mathrm{b}$ is in making the economic decisions of transition from converging on equilibrium value without oscillation. Under current economic conditions the external financial position is under substantial risk of moving in the direction from stable equilibrium to "further and further from the equilibrium value" (Shone, 2003, p. 10).

The current economic situation in the national economy reflects the pessimistic scenario of moving away from the stable equilibrium value (in the direction of unique and global instability), despite

\section{Nonlinear dynamics:}

The basic value of the sovereign debt time path, as in the linear case, proceeds from the zero level of sovereign debt in $1991(\mathrm{X}(0)=0)$ but with two fixed points in the system and local instability. The recursive nonlinear system is presented in the form:

$x(t+1)=-0.007 x^{2}+0.0161 x-0.1132 \quad x(0)=0$

The calculation within the above presented formula (1) has created the nonlinear formula with the appropriate graph of the following type:

Contrary to the case with the linear dependency, the system is starting to oscillate between the values of 0 and 11 .

The general model of sovereign debt on Figure 5 is presented using 3 interrelated stocks. The primary deficit reflects the initial point for sovereign debt emergence with further influence on national wealth. The stock-flow adjustment reflects the gap between the deficit flow and the stock of the government debt with appropriate influence on national wealth.

The stock and flows diagram has one balancing and one reinforcing loop, which determines some restrictions on "snowball sovereign debt effect" in the national economy.

Simulation modelling. The simulation modelling determines the current state of sovereign debt dynamics under condition of short - term (4 years) 


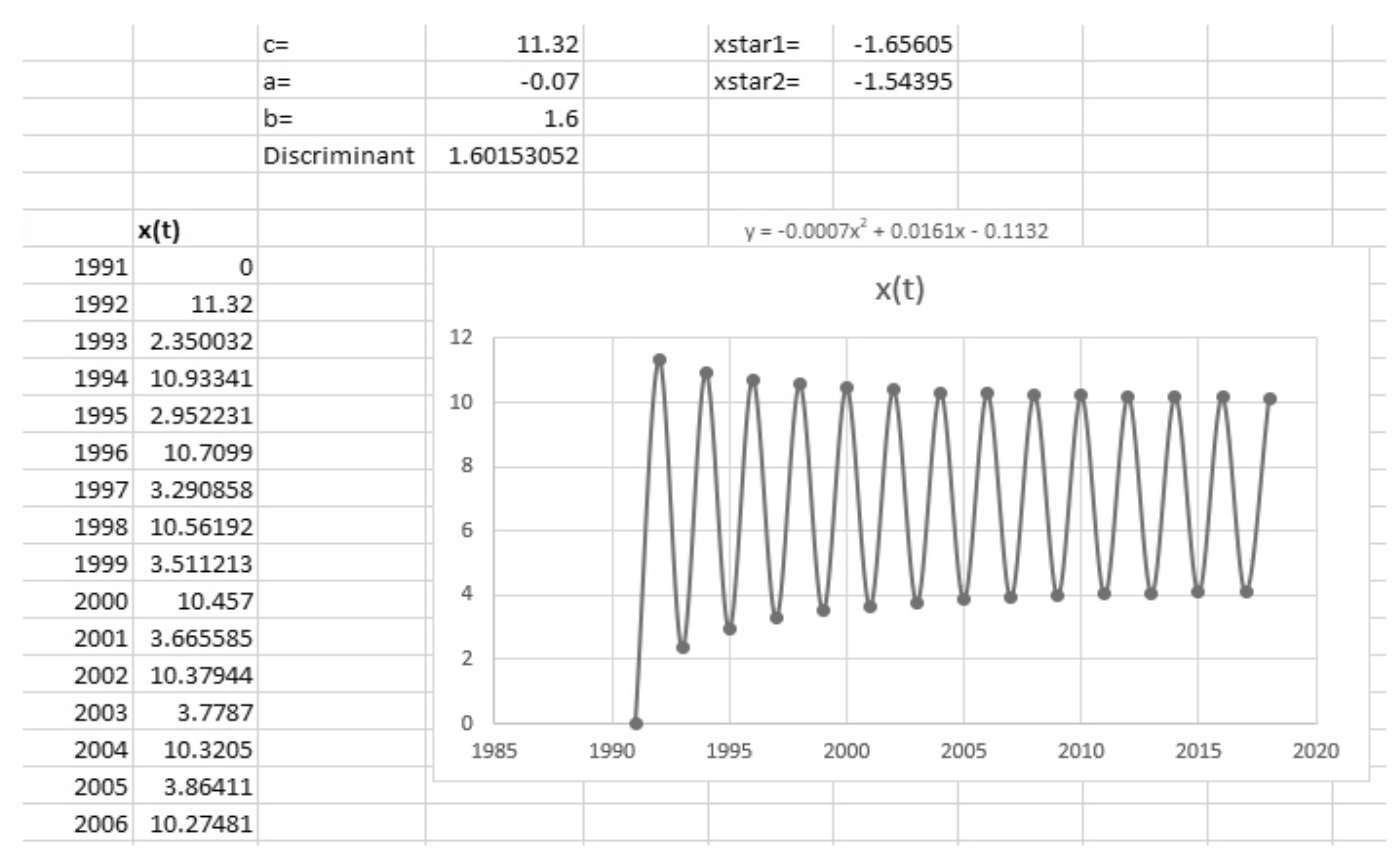

Fig. 4. The fixed point as an equilibrium value for a country's sovereign debt stock to GDP ratio with a nonlinear dependence (fragment of the calculation) Source: own calculations, based on (Shone, 2003)

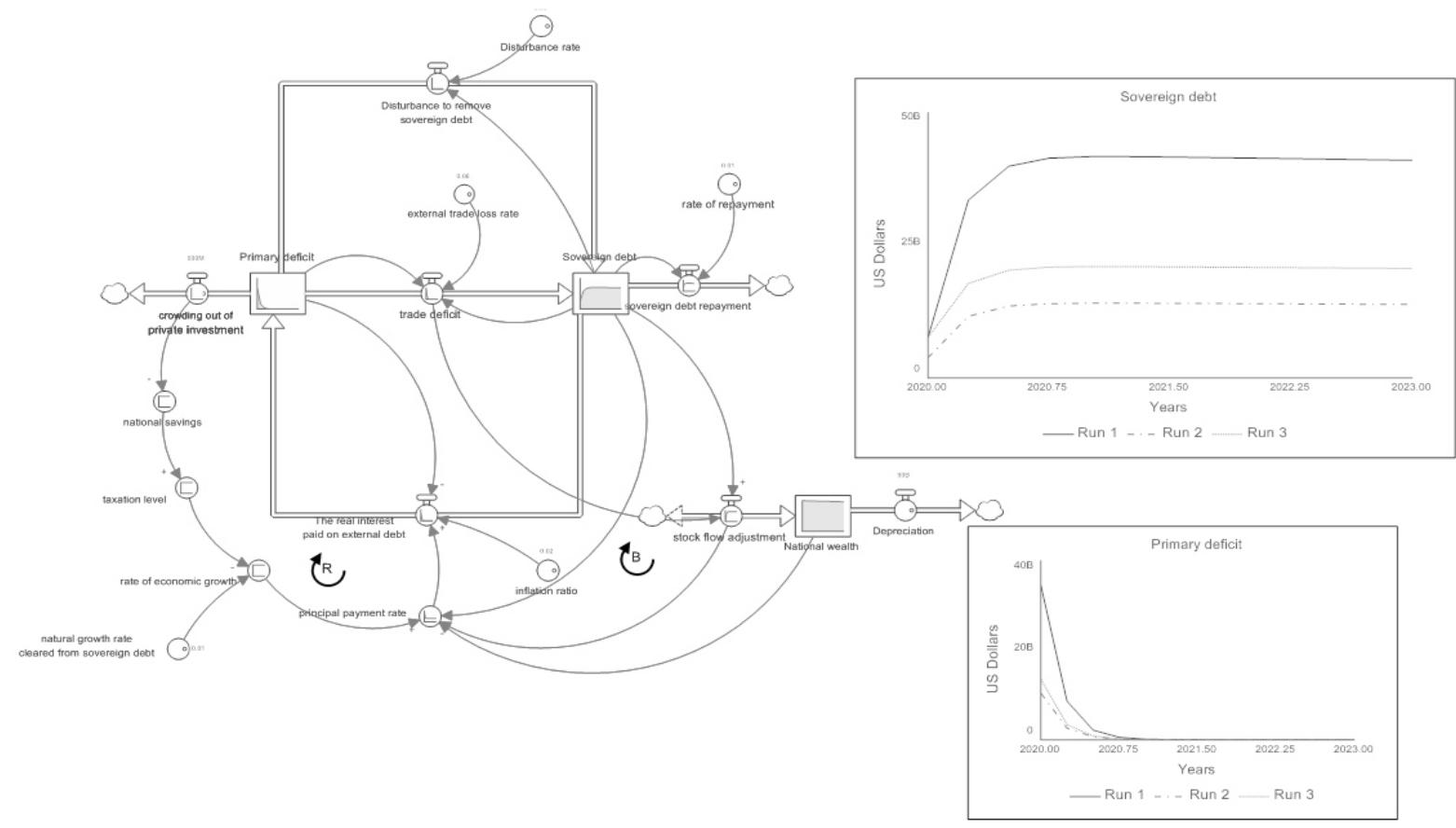

Fig. 5. SD modelling and simulation analysis of sovereign debt in Ukrainian economy Source: own calculations

development. The economy is not under condition of equilibrium until the end of 2021. The 3 simulative runs of sovereign debt are compared with the similar simulation for primary deficit level. The analysis indicates that under zero primary deficit the sovereign debt stipulates the government to borrow more. The results of simulation may be reflected in 3 possible scenarios: sharp decreasing of primary deficit with appropriate sovereign debt radical increasing; moderate decreasing of primary deficit with appropriate sovereign debt moderate increasing; the lowest level of primary deficit dynamics reflects the lowest level of sovereign debt.

Conclusions and further research proposals. The optimal level of sovereign debt reflects not just derivative from the government deficit level but by 
itself reflects the emergence of internal imbalances in the national economy. The principal issue is not in complete elimination of sovereign debt, but in finding the optimal balancing level both for it and national budget deficit with the purpose of possible oscillation process elimination. The optimal sovereign debt level mirrors the future scenarios for national wealth increasing and connected with optimal taxation level, inflation rate and especially stock-flow adjustment which may reduce the possible crowding out of private investment. The precarious economic and geopolitical situation in Ukraine requires to take appropriate steps to avoid the new debt restructuring or even default scenario.

One of the main ideas of our research was to show that the sovereign debt can reduce substantially national wealth with or without existence of budget deficit. The sovereign debt can decrease national saving and create the reinforcing loop with a higher sovereign debt interest rate. Those negative consequences may be substantially reduced by sovereign debt repayment and economic growth, which are not overlapped by the depreciation process.

The dynamic recursive models were also presented in the study to show the non - linear interdependence of the indicators, which are the basis for the "snowball sovereign debt effect".

The scenario analysis was introduced in the very basic form to present the interrelation between primary deficit development and sovereign debt dynamics with the sharp, moderate, and the lowest level of change. It will allow to generate the quantified model with appropriate indicators in further research.

Future studies will be oriented onto managing and elaborating the stocks (primary deficit, sovereign debt, and national wealth) from external debt management point of view, finding and scientific explanation of the oscillations in the existing system with the rationale of their possible minimization or even elimination.

\section{References}

Borensztein, E. (1990). Debt overhang, credit rationing and investment. Journal of Development Economics, 32(2), 315-355.

Cha, H. (2019). Self-organization for strategic adoption under disequilibrium. (Doctor of Philosophy thesis). Temple University, Philadelphia.

David, P. (1985). Clio and the Economics of QWERTY. American Economic Review, Papers and Proceedings of the NinetySeventh Annual Meeting of the American Economic Association, 75(2), 332-337.

Escolano, J. (2010). A Practical Guide to Public Debt Dynamics, Fiscal Sustainability, and Cyclical Adjustment of Budgetary Aggregates. International Monetary Fund. imf.org. https:// www.imf.org/en/Publications/TNM/Issues/2016/12/31/A-Practical-Guide-to-Public-Debt-Dynamics-Fiscal-Sustainabilityand-Cyclical-Adjustment-of-23498

Hugh, E. (2010). The debt snowball problem. A fistful of Euros. European opinion. fistfulofeuros.net. http://fistfulofeuros.net/afoe/ the-debt-snowball-problem/
Kuhn, T. S. (1970). The Structure of Scientific Revolutions (2nd ed.). Chicago: University of Chicago Press.

Picarelli, M., Vanlaer, W., \& Marneffe, W. (2019). Does public debt produce a crowding out effect for public investment in the EU? European Stability Mechanism. Working Paper Series No. 36. DOI: $10.2852 / 795853$

Shone, R. (2003). An introduction to economic dynamics. New York, Melbourne: Cambridge University Press.

State Statistics Service of Ukraine. (2020). ukrstat.gov.ua. http:// www.ukrstat.gov.ua/imf/arhiv/zb/zb_u_.htm

Sterman, J. D., \& Wittenberg, J. (1999). Path dependence, competition, and succession in the dynamics of scientific revolution. Organization Science, 10(3), 322-341.

Vergne, J.-P., \& Durand, R. (2010). The Missing Link Between the Theory and Empirics of Path Dependence: Conceptual Clarification, Testability Issue, and Methodological Implications. Journal of Management Studies, 47(4) June, 735-759.

Григор'єв Г. С.

\section{ТРАЄКТОРІЯ ЗАЛЕЖНОСТІ В МОДЕЛЮВАННІ СУВЕРЕННОГО БОРГУ: СИСТЕМНО-ДИНАМІЧНИЙ ПІДХІД}

Мета дослідження. У статті запропоновано системно-динамічне моделювання суверенного боргу з використанням концепції траєкторії залежності. Методи дослідження: за допомогою використання системно-динамічного імітаційного моделювання автор намагається знайти нерухому точку в русі національного суверенного боргу в напрямку його рівноваги з відповідною зміною сприйняття існуючої ментальної моделі щодо суверенного боргу за допомогою зміни структури системи.

Результати дослідження. Дослідження розкриває ідею концепції боргових «снігових куль» за допомогою рекурсивного динамічного підходу. Побудовано динамічні лінійні та нелінійні рекурсивні моделі державного боргу України з відповідними багаторядними рекурсивними рівняннями. Визначено нерухому точку як значення рівноваги для співвідношення суверенного боргу країни до ВВП з лінійною залежністю. Визначено фіксовану точку як значення рівноваги для відношення суверенного боргу країни до ВВП з нелінійною залежністю. Основною метою цієї частини аналізу було показати більш складну осциляторну поведінку системи та кратність можливих точок рівноваги. 
Можливе застосування результатів дослідження. Пошук початкової точки для вирішення питання державного боргу особливо актуальний для національної економіки під сильним фіскальним тиском, спричиненим COVID-19 та воєнними подіями на Сході країни. 3 цією метою також було відтворено циклічну поведінку суверенного боргу за допомогою графіка фазової діаграми. Моделювання та імітаційний аналіз запасів і потоків державного боргу в українській економіці дають змогу зробити висновок про неминучість існування державного боргу навіть на стабільному рівні та зі збалансованим національним бюджетом.

Висновки. Оптимальний рівень державного боргу відображає не просто похідну від рівня державного дефіциту, а появу внутрішніх дисбалансів у національній економіці. Основне питання полягає не в повній ліквідації державного боргу, а в пошуку оптимального рівня балансування як для нього, так i для дефіциту національного бюджету з метою усунення можливого коливального процесу.

Оптимальний рівень державного боргу відображає майбутні сценарії збільшення національного багатства, пов'язані з оптимальним рівнем оподаткування, рівнем інфляції та особливо регулюванням потоку запасів, що може зменшити можливе витіснення приватних інвестицій. Нестабільна економічна та геополітична ситуація в Україні вимагає вжити відповідних заходів, щоб уникнути нової реструктуризації боргу або навіть сценарію дефолту.

Однією з головних ідей дослідження було показати, що суверенний борг може суттєво зменшити національне багатство з наявністю або без дефіциту бюджету. Суверенний борг може зменшити національні заощадження та створити посилювальну петлю з вищою процентною ставкою державного боргу. Ці негативні наслідки можуть істотно зменшити погашення державного боргу та економічне зростання, які не перекриваються процесом амортизації основного капіталу.

Ключові слова: системна динаміка, траєкторія залежності, концепція боргової «снігової кулі», лінійна та нелінійна модель суверенного боргу, коливання, фіксація.

Матеріал надійшов 19.04.2021

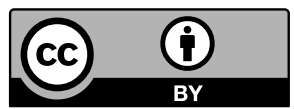

Creative Commons Attribution 4.0 International License (CC BY 4.0) 